\title{
Analisis Kemampuan Pemahaman Konsep Matematis Siswa Dalam Materi Sistem Persamaan Linear Dua Variabel
}

\author{
Maryam Alzanatul Umam*, Rafiq Zulkarnaen \\ Pendidikan Matematika, Universitas Singaperbangsa Karawang, Indonesia \\ *Coresponding Author: 1810631050041@student.unsika.ac.id
}

Article History:

Received 2022-01-29

Revised 2022-02-24

Accepted 2022-03-05

DOI:

10.31949/educatio.v8i1.1993

\begin{abstract}
The low ability to understand mathematical concepts is evidenced by the fact that most students cannot reformulate the solution to the given problem. Therefore, the purpose of this research is to examine the ability to understand mathematical concepts of class IX students in solving problems related to the material of the Two Variable Linear Equation System. In this study, a qualitative descriptive method was used. Simple Random Sampling technique that researchers use to select research subjects. 13 students at one MTs in Karawang Regency became the research subjects. Test and non-test instruments were used in this study, three descriptive questions containing indicators restating a concept, presenting concepts into mathematical representations, applying algorithmic concepts in problem solving. Furthermore, for the non-test instrument in the form of unstructured interviews to find out students' difficulties. Based on the results of data studies that have been carried out, the percentage of students who are able to restate a concept reaches $23.08 \%$, presents concepts into mathematical representations reaches $53.85 \%$, and applies algorithmic concepts in problem solving reaching $30.77 \%$. So, it can be concluded that the students' ability to understand mathematical concepts when working on SPLDV questions as a whole is relatively low, with a percentage of $35.90 \%$. The causal factors that also influence the acquisition of the low percentage of students' understanding of mathematical concepts are lack of concentration in learning, irregular study habits and unattractive learning methods.
\end{abstract}

Keywords: learning concentration factors and learning models; concept understanding; mathematical representation; two-variable linear equation system. 


\section{PENDAHULUAN}

Matematika adalah pelajaran yang mewajibkan siswa untuk mampu berpikir analitis dan terorganisasi (Purba, 2019). Oleh sebab itu, siswa wajib mempelajari matematika sejak pendidikan Sekolah Dasar sampai Perguruan Tinggi. Pada proses belajar matematika erat kaitannya dengan pemahaman konsep, karena pada saat mengerjakan persoalan matematika siswa harus bisa memahami suatu konsep terlebih dahulu, sebagaimana pernyataan dari Zulkardi (dalam Basir \& Karmila, 2011) bahwa pelajaran matematika lebih memusatkan kepada konsep. Kemampuan pemahaman matematis merupakan suatu penguasaan awal yang wajib siswa miliki untuk bisa mengkonstruksi suatu makna. Pemahaman adalah kemampuan siswa dalam menginterpretasikan sesuatu yang sudah diketahui dan dimengerti yang kemudian dapat menjelaskan serta mengkomunikasikannya kepada orang lain (Febriyanto et al., 2018). Dalam mempelajari matematika, siswa harus mampu menguasai sejumlah konsep. Ide abstrak seseorang untuk mampu menggolongkan apakah satu fenomena atau peristiwa termasuk ke dalam contoh atau noncontoh merupakan pengertian dari konsep (Fajar et al., 2018).

Kemampuan pemahaman konsep adalah suatu keterampilan yang berkaitan dengan menerjemahkan gagasan matematika yang global dan fungsional (Lestari \& Yudhanegara, 2018). Pemahaman suatu konsep merupakan komponen pokok pelaksanaan proses belajar matematika, jika siswa mampu menginterpretasikan banyak konsep maka siswa akan lebih baik lagi dalam memecahkan masalah, karena ketika memecahkan suatu masalah diperlukan adanya ketentuan-ketentuan yang berlandaskan pada konsep-konsep yang telah dimiliki. Dalam kemampuan pemahaman konsep, siswa harus mampu menjelaskan kembali materi dan mampu menyelesaikan berbagai permasalahan atau pemecahan masalah matematika sesuai dengan konsep yang telah mereka dapatkan. Siswa dapat dianggap sudah mampu menguasai suatu konsep matematis, bila siswa telah memenuhi indikator pemahaman konsep matematis. Namun nyatanya pada proses pembelajaran matematika ditumbuh kembangkan melalui paradigma pembelajaran sintesis, pemberian contoh soal dan latihan. Pada saat pembelajaran, tidak sedikit siswa mengalami kesulitan saat mengartikan suatu konsep matematika yang ditandai dengan kurang mampunya siswa ketika menyatakan kembali solusi dari sebuah permasalahan, seperti pada saat mengerjakan soal berbentuk prosa dalam materi SPLDV, siswa juga tengah kesusahan untuk mengubah persoalan tersebut menjadi model matematika. Ketika proses pembelajaran berlangsung siswa hanya menuliskan kembali materi dan contoh yang guru sampaikan tanpa memahaminya dengan baik, sehingga saat diberikan soal yang lain daripada contoh yang sudah dibahas pada pertemuan sebelumnya, siswa sulit memahaminya yang pada akhirnya siswa tidak bisa menuntaskan jawabannya dengan tepat. Jika kebiasaan buruk tersebut tidak segera diatasi, maka siswa akan tumbuh menjadi siswa yang kolokan dengan menganggap bahwa gurulah satu-satunya sumber belajar sehingga diperolehlah hasil belajar yang buruk. Oleh karenanya, diperlukannya inovasi dalam berjalannya kegiatan belajar mengajar yang disusun guru agar konsep matematika dapat dipahami dan dipelajari siswa (Putri, 2012).

Pemahaman konsep, teorema, kaidah dan rumus-rumus matematika bisa diwujudkan dengan benar jika siswa mampu memfokuskan perhatiannya pada bahan ajar yang nantinya dipelajari serta memperbanyak mengerjakan latihan-latihan secara rutin, namun jika memusatkan semua perhatian tersebut maka siswa akan sangat sulit untuk melakukannya di kelas sebab terdapat sejumlah faktor yang mengakibatkan proses pemahaman konsep pun tidak dapat dikuasai sepenuhnya oleh para siswa. Faktor yang turut berpengaruh pada pemahaman konsep siswa diantaranya terdapat faktor dari dalam (internal) mencakup kognitif siswa, kepribadian siswa, perilaku saat belajar, semangat belajar, konsentrasi belajar, mengolah bahan belajar, menggali hasil belajar, rasa percaya diri, dan kebiasaan belajar sedangkan faktor dari luar (eksternal) antara lain: sekolah, guru, teman sebaya, dan model pembelajaran yang guru gunakan (Aunurrahman, 2013).

Berdasarkan hasil wawancara dengan guru matematika kelas IX pada satu MTs di Kabupaten Karawang, ternyata sebagian besar siswa memberikan hasil yang kurang baik untuk mata pelajaran matematika. Kelas IX yang terdiri dari delapan kelas pada umumnya hasil ulangan yang dihasilkan belum 
mencapai KKM. Siswa tidak mengerti bagaimana belajar dengan efisien dan efektif dikarenakan mereka hanya berusaha untuk menghafalkan rumus saja tetapi tidak memahaminya dengan baik. Oleh sebab itu, jika siswa diberikan tes, siswa tidak bias menjawabnya. Siswa kerap merasa kesusahan ketika menafsirkan soal dan memilih model matematika yang disebabkan oleh kurang cermatnya siswa dalam menangkap informasi-informasi penting yang digunakan dalam penyelesaian soal. Padahal dalam belajar matematika bukan sekedar menghafal rumus, melainkan perlu adanya proses penalaran dan pemahaman konsep yang baik. Rendahnya kemampuan pemahaman konsep juga bisa ditunjukkan berdasarkan penelitian (Yufentya et al., 2019) menyatakan bahwa siswa yang berkemampuan tinggi sudah mempunyai kemampuan pemahaman konsep pada materi lingkaran dengan baik namun siswa yang memiliki kemampuan sedang dan rendah, kemampuan pemahaman konsepnya kurang baik. Hal yang menjadikan pemahaman konsep siswa menjadi rendah dikarenakan kurangnya keikutsertaan siswa dalam membentuk konsep secara mandiri dan sebatas mengingat rumus yang diberikan saja sehingga pemahaman siswa belum cukup baik dalam materi lingkaran. Adapun menurut (Kartika, 2018) mengatakan bahwa dari total siswa sejumlah 30 orang, kemampuan pemahaman konsep pada materi aljabar secara menyeluruh masih terbilang rendah. Terjadinya hal tersebut karena siswa kurang memperhatikan materi bentuk aljabar. Perbedaan dengan penelitian sebelumnya yaitu peneliti ingin menganalisis kemampuan siswa dalam memahami materi SPLDV.

Penelitian ini dilakukan untuk mengetahui kemampuan pemahaman konsep siswa dalam belajar matematika dan kesulitan apa yang dihadapi siswa pada saat mengerjakan persoalan materi SPLDV yang beracuan pada indikator pemahaman konsep matematis. Manfaat dari hasil penelitian ini yaitu guru bisa lebih mempertimbangkan lagi metode seperti apa yang mampu menunjang keberhasilan dalam pembelajaran.

\section{METODE PENELITIAN}

Metode penelitian yang digunakan yaitu deskriptif kualitatif. Bentuk data primer dalam penelitian ini yakni hasil jawaban tes uraian tertulis mengenai permasalahan yang berhubungan dengan materi SPLDV dan hasil wawancara mengenai kesulitan siswa dalam menjawab pertanyaan-pertanyaan yang diberikan serta dilengkapi dengan data dokumentasi seperti foto. Mereduksi dan mempresentasikan data, serta menarik kesimpulan merupakan teknik dalam menganalisis data penelitian.

Tahapan penelitian dilaksanakan pada bulan November 2021. Penelitian dilakukan pada siswa kelas IX pada satu MTs di Kabupaten Karawang. Kelas IX tersebar dalam delapan kelas. Teknik yang digunakan untuk pemilihan subjek penelitian yaitu dengan teknik Simple Random Sampling. Kelas yang peneliti pilih untuk dilakukan penelitian yaitu kelas IX D yang berjumlah 27 siswa yang terpecah menjadi dua grup yaitu dengan pembelajaran daring dan pembelajaran tatap muka terbatas. Namun yang terpilih untuk dijadikan subjek penelitian ialah grup yang sedang melakukan pembelajaran tatap muka terbatas yaitu sebanyak 13 siswa. Tes dilakukan sesudah siswa mempelajari substansi pembahasan SPLDV.

Teknik pengumpulan data yaitu melalui pemberian tes dan wawancara. Hal pertama yaitu pemberian tes. Menurut Arifin (2011), tes merupakan deretan permasalahan atau pekerjaan yang harus dikerjakan untuk menilai kemampuan siswa. Dalam menilai kemampuan pemahaman konsep siswa yaitu dengan menggunakan instrumen penelitian berupa tes uraian sebanyak 3 soal yang telah disesuaikan berdasarkan tiap-tiap indikator pemahaman konsep matematis dengan tahapan-tahapan yang dilakukan yaitu: peneliti membagikan lembar tes yang berisikan soal uraian, setelah dilaksanakan tes peneliti menganalisis jawaban siswa kemudian menghitung berapa persen siswa yang sudah memahami konsep matematis dengan baik sesuai indikator yang dimuat dalam setiap butir soal serta faktor apa yang mempengaruhinya. Untuk melengkapi data penelitian, maka perlu dilakukan wawancara. Wawancara tidak terstruktur dilakukan dalam penelitian ini. Wawancara dilakukan ketika siswa menyelesaikan soal-soal tes uraian agar peneliti tahu kesulitan yang dialami oleh siswa. 
Adapun indikator pemahaman konsep matematis siswa menurut Zuliana (2017) diantaranya: menyatakan kembali sebuah konsep, mengelompokkan objek-objek berdasarkan karakter khusus, memberikan contoh dan noncontoh dari konsep, menyajikan konsep dalam berbagai bentuk representasi matematis, mengembangkan syarat perlu atau syarat cukup suatu konsep, menggunakan, memanfaatkan, dan memilih prosedur atau operasi tertentu, mengaplikasikan konsep atau algoritma pemecahan masalah.

Kriteria penilaian kemampuan pemahaman konsep matematika setelah dimodifikasi dari Mawaddah \& Maryanti (2016) bisa dilihat pada tabel 1.

Tabel 1. Pedoman Penskoran Kemampuan Pemahaman Konsep Matematis

\begin{tabular}{|c|c|c|}
\hline $\begin{array}{l}\text { Indikator Pemahaman } \\
\text { Konsep }\end{array}$ & Keterangan & Skor \\
\hline Menyatakan kembali & Tidak menjawab & 0 \\
\hline \multirow[t]{4}{*}{ sebuah konsep } & Tidak mampu menyatakan kembali konsep & 1 \\
\hline & $\begin{array}{l}\text { Mampu menyatakan kembali konsep namun masih terdapat } \\
\text { kekeliruan }\end{array}$ & 2 \\
\hline & Mampu menyatakan kembali konsep namun belum tepat & 3 \\
\hline & Mampu menyatakan kembali konsep dengan tepat & 4 \\
\hline \multirow{5}{*}{$\begin{array}{l}\text { Menyajikan konsep } \\
\text { dalam berbagai bentuk } \\
\text { representasi } \\
\text { matematika }\end{array}$} & Tidak menjawab & 0 \\
\hline & $\begin{array}{l}\text { Mampu menyajikan sebuah konsep dalam bentuk } \\
\text { representrasi matematis namun belum tepat dan masih } \\
\text { banyak kekeliruan }\end{array}$ & 1 \\
\hline & $\begin{array}{l}\text { Mampu menyajikan sebuah konsep dalam bentuk } \\
\text { representasi matematis namun kurang lengkap }\end{array}$ & 2 \\
\hline & $\begin{array}{l}\text { Mampu menyajikan sebuah konsep dengan benar namun } \\
\text { kurang lengkap }\end{array}$ & 3 \\
\hline & $\begin{array}{l}\text { Mampu menyajikan sebuah konsep dengan benar dan } \\
\text { lengkap }\end{array}$ & 4 \\
\hline \multirow{5}{*}{$\begin{array}{l}\text { Mengaplikasikan } \\
\text { konsep atau algoritma } \\
\text { pada pemecahan } \\
\text { masalah }\end{array}$} & Tidak menjawab & 0 \\
\hline & $\begin{array}{l}\text { Tidak mampu mengaplikasikan rumus sesuai prosedur } \\
\text { dalam menyelesaikan soal pemecahan masalah }\end{array}$ & 1 \\
\hline & $\begin{array}{l}\text { Mampu mengaplikasikan rumus sesuai prosedur dalam } \\
\text { menyelesaikan soal pemecahan masalah namun masih } \\
\text { banyak kekeliruan }\end{array}$ & 2 \\
\hline & $\begin{array}{l}\text { Mampu mengaplikasikan rumus sesuai prosedur dalam } \\
\text { menyelesaikan soal pemecahan masalah namun belum tepat }\end{array}$ & 3 \\
\hline & $\begin{array}{l}\text { Mampu mengaplikasikan rumus sesuai prosedur dalam } \\
\text { menyelesaikan soal pemecahan masalah dengan tepat }\end{array}$ & 4 \\
\hline
\end{tabular}

Selanjutnya menunjukkan seberapa tinggi persentase kemampuan pemahaman konsep matematis siswa menurut Andini (2021). Bisa kita lihat kriteria interpretasi skor dalam tabel 2.

Tabel 2. Kriteria Interpretasi Skor Kemampuan Pemahaman Konsep Matematis

\begin{tabular}{ccc}
\hline No & Persentase & Tingkat Pemahaman \\
\hline 1. & $0 \%-20 \%$ & Kurang Sekali \\
2. & $21 \%-40 \%$ & Kurang \\
3. & $41 \%-60 \%$ & Cukup \\
4. & $61 \%-80 \%$ & Baik \\
5. & $81 \%-100 \%$ & Sangat Baik \\
\hline
\end{tabular}


Rumus persentase skor kemampuan pemahaman konsep matematis sebagai berikut :

$x=\frac{a}{b} 100 \%$

Keterangan:

$x=$ Persentase jawaban benar siswa

$a=$ Skor jawaban benar

$b=$ Skor maksimal yang mungkin dicapai

\section{HASIL DAN PEMBAHASAN}

Penelitian ini memiliki tujuan untuk mengetahui kemampuan pemahaman konsep matematika siswa saat menuntaskan soal mengenai materi SPLDV. Dalam menganalisis kemampuan pemahaman konsep matematis siswa, peneliti memberikan soal berupa uraian yang sudah di validasi. Permasalahan yang diberikan kepada siswa yaitu sebanyak 3 soal uraian yang tiap butir soalnya sudah termuat beberapa indikator pemahaman konsep matematis. Ringkasan persentase kemampuan pemahaman konsep matematis siswa disajikan dalam tabel 3.

Tabel 3. Interpretasi Kemampuan Pemahaman Konsep Matematis Siswa

\begin{tabular}{|c|c|c|c|c|}
\hline \multirow[t]{2}{*}{ No } & \multirow[t]{2}{*}{ Indikator } & \multicolumn{3}{|c|}{ Menguasai Indikator } \\
\hline & & $\begin{array}{c}\text { Jumlah } \\
\text { Siswa }\end{array}$ & Persentase & Kategori \\
\hline 1 & Menyatakan kembali sebuah konsep & 3 & $23,08 \%$ & Kurang \\
\hline 2 & $\begin{array}{l}\text { Menyajikan konsep dalam berbagai bentuk } \\
\text { representasi matematika }\end{array}$ & 7 & $53,85 \%$ & Cukup \\
\hline 3 & $\begin{array}{l}\text { Mengaplikasikan konsep atau algoritma pada } \\
\text { pemecahan masalah }\end{array}$ & 4 & $30,77 \%$ & Kurang \\
\hline & Jumlah Rata-rata & & $35,90 \%$ & Kurang \\
\hline
\end{tabular}

Berdasarkan data pada Tabel 3, apabila kita amati dari setiap indikator yang dimuat, hanya sebagian siswa yang sudah mampu menguasai. Indikator kemampuan pemahaman konsep yang pertama yaitu menyatakan kembali sebuah konsep merupakan indikator paling sedikit dikuasai oleh siswa. Terlihat pada tabel 3, hanya 3 siswa yang sudah menguasai indikator tersebut dengan persentase sebesar 23,08 \%. Indikator kedua yaitu menyajikan konsep dalam berbagai bentuk representasi matematika merupakan indikator paling banyak dikuasai oleh siswa, ada sebanyak 7 siswa dengan persentase sebesar 53,85\% yang sudah mampu menguasai indikator tersebut. Indikator ketiga yaitu mengaplikasikan konsep atau algoritma pada pemecahan masalah yang sudah mampu menguasai hanya 4 siswa dengan persentase sebesar $30,77 \%$. Sehingga bisa kita ketahui bahwa sebagian besar kemampuan pemahaman konsep pada siswa kelas IX dalam menyelesaikan soal SPLDV secara keseluruhan masih tergolong rendah dengan persentase sebesar 35,90\%. Hal ini disebabkan masih banyaknya siswa yang belum mampu memperoleh skor maksimum disetiap indikator kemampuan pemahaman konsep.

Selanjutnya, menganalisis hasil jawaban siswa dalam mencari solusi dari soal-soal yang berhubungan dengan materi SPLDV sebagai berikut:

\section{Indikator: menyatakan kembali sebuah konsep}

Soal nomor 1, "Jelaskan apa yang dimaksud dengan SPLDV?"

Pada indikator pertama yang berlandaskan pada jawaban siswa dengan jawaban benar sebanyak 3 siswa. Mengacu pada pedoman penskoran kemampuan pemahaman konsep matematis pada Tabel 1 dan rumus persentase skor kemampuan pemahaman konsep matematis di atas, maka perhitungan yang dilakukan yaitu dengan mengalikan jumlah siswa dengan jawaban benar sebanyak 3 orang dengan skor 
jawaban benar yang terdapat pada Tabel 1 yang bernilai 4 dan hasil perkalian yang didapat adalah 12 . Kemudian, 12 dibagi dengan skor maksimal yang mungkin dicapai artinya 4 dikalikan dengan subjek penelitian sebanyak 13 siswa yang menghasilkan 52. Oleh karena itu, 12 kita bagi dengan 52 maka diperoleh hasilnya adalah 0,2308 yang kemudian dikalikan dengan 100\%, sehingga diperoleh persentase skor sebesar 23,08\%. Dengan demikian, kemampuan siswa dalam menyatakan kembali sebuah konsep dikategorikan kurang. Apabila kita lihat dari hasil wawancara yang sudah dilakukan, yang menjadi faktor penyebab rendahnya pemerolehan persentase tersebut adalah kurangnya konsentrasi siswa dalam belajar, sehingga ketika guru memberikan pemahaman mengenai pengertian SPLDV siswa tidak menyimak dengan baik. Berikut merupakan penjabaran kemampuan siswa pada indikator pertama soal nomor satu.

\section{1.) SpLov adalah Sistem Persamoan Linear Dua Variabel dengan menggunakan metode substitusi dan eliminasi}

Gambar 1. Jawaban benar siswa

Pada soal nomor 1 siswa diharapkan mampu menyatakan kembali sebuah konsep. Berikut merupakan satu dari tiga jawaban siswa yang memenuhi indikator pertama. Berdasarkan gambar 1 bisa dilihat bahwa siswa telah mampu menyatakan kembali sebuah konsep dengan baik, walaupun jawabannya belum sepenuhnya benar. Namun, siswa tersebut sudah mampu menyatakan kembali sebuah konsep dengan bahasanya sendiri, karena jika dilihat dari jawabannya siswa sedikitnya telah mengingat metode yang biasa digunakan untuk mengerjakan soal materi SPLDV. Sehingga, siswa tersebut terbilang sudah mampu menyatakan kembali sebuah konsep.

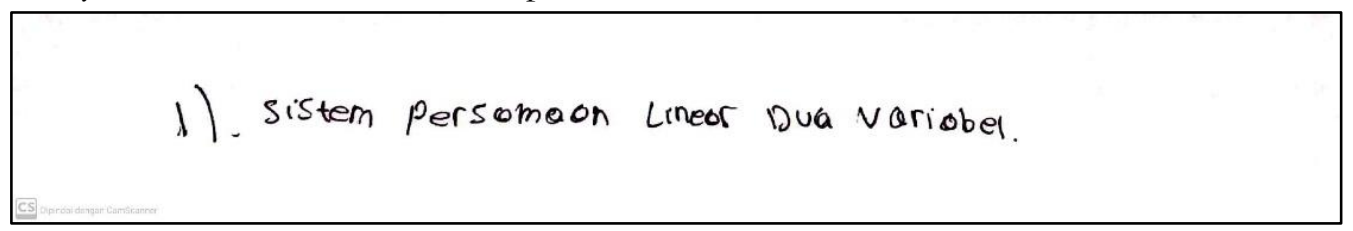

Gambar 2. Jawaban salah siswa

Berdasarkan Gambar 2 yang merupakan salah satu jawaban yang salah, nampak jawaban siswa yang menuliskan kepanjangan SPLDV saja tanpa memberikan pengertian yang jelas dengan bahasanya sendiri. Sehingga, dapat kita katakan bahwa siswa tersebut tidak dapat menyatakan kembali sebuah konsep dengan tepat.

Bersumber dari hasil wawancara siswa dengan jawaban salah, siswa tidak teliti saat mengartikan soal karena siswa tergesa-gesa ketika mengerjakannya. Sebagaimana pada penelitian Ananda yang menunjukkan bahwa dari keseluruhan jawaban, siswa mengalami kesalahan konsep sebesar 33,33\%, kesalahan ini dikarenakan siswa belum mengetahui apa yang menjadi pertanyaan dalam soal tersebut sehingga penyelesaian yang dihasilkan pun menjadi salah (Ananda et al., 2018).

\section{Indikator: menyajikan konsep kedalam bentuk representasi matematis}

Soal nomor 2 :

Lima sampan besar dan dua sampan kecil dapat mengangkat 45 orang. Dua sampan besar dan satu sampan kecil dapat mengangkat 27 orang.

a. Tulislah dua persamaan matematika yang menyatakan informasi diatas. gunakan huruf b dan k untuk variabel!

b. Menunjukkan apa huruf $\mathrm{b}$ dan $\mathrm{k}$ pada persamaan yang kamu tulis?

Pada indikator kedua, yang menjawab dengan benar sebanyak 7 siswa. Beracuan pada tabel 1 pedoman penskoran kemampuan pemahaman konsep matematis dan rumus persentase skor kemampuan pemahaman konsep matematis di atas, tahap perhitungannya yaitu mengalikan jumlah siswa dengan jawaban benar sebanyak 7 siswa dengan skor jawaban benar yang terdapat pada Tabel 1 yang bernilai 4 dan hasil perkalian yang didapat adalah 28. Kemudian, 28 dibagi dengan skor maksimal yang mungkin 
dicapai artinya 4 dikalikan dengan subjek penelitian sebanyak 13 siswa yang menghasilkan 52 . Oleh karena itu, 28 kita bagi dengan 52 maka diperoleh hasilnya adalah 0,5385 yang kemudian dikalikan dengan 100\%, sehingga diperoleh persentase skor sebesar 53,85\%. Dengan demikian, dapat diartikan bahwa kemampuan siswa dalam menyajikan konsep kedalam bentuk representasi matematis dikategorikan cukup. Jika kita perhatikan dari hasil wawancara yang sudah dilakukan, faktor yang berpengaruh terhadap rendahnya pemerolehan persentase tersebut adalah kebiasaan belajar siswa yang hanya menerima apa yang guru berikan saja, sedangkan saat proses pemebelajaran pun siswa sulit untuk fokus. Berikut penjelasan kemampuan siswa pada indikator kedua soal nomor dua

2. a) $5 b+2 k=45$ orang
$2 b+1 k=27$."
b) $b=$ sampar besar
$k=$ sampar kecir

Gambar 3. Jawaban benar siswa

Pada soal nomor 2 diharapkan siswa mampu menyajikan konsep kedalam bentuk representasi matematis atau biasa kita kenal dengan mengubah soal cerita menjadi kalimat matematika. Berdasarkan Gambar 3 yang merupakan satu dari 7 siswa yang menjawab benar, nampak pada jawaban siswa yang sudah mampu menyajikan konsep ke dalam bentuk representasi matematis dengan tepat, lantaran siswa sudah dapat mengenali fakta yang ada dalam soal, huruf $b$ yang menyatakan sampan besar dan huruf $k$ yang menyatakan sampan kecil. Sehingga dengan begitu siswa juga mampu menyatakan persamaan matematika yang diminta pada soal. Dengan demikian siswa dinyatakan cukup baik dalam menguasai indikator tersebut.

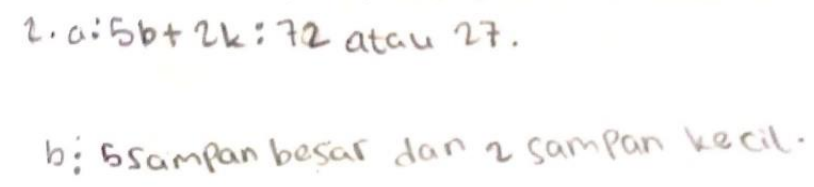

Gambar 4. Jawaban salah siswa

Berdasarkan Gambar 4 yang merupakan salah satu siswa dengan jawaban salah. Dapat dilihat bahwa siswa belum mampu menyajikan konsep kedalam bentuk representasi matematis, karena siswa tidak dapat mengidentifikasi keterangan yang terdapat di dalam soal. Oleh karena itu, siswa tidak bisa menyatakan huruf mana yang merupakan sampan besar maupun sampan kecil, dengan demikian siswa pun tidak dapat menuliskan persamaan matematika yang diperintahkan dalam soal tersebut.

Berdasarkan hasil wawancara siswa dengan jawaban salah, menyatakan bahwa pada saat siswa menuliskan pemodelan matematika dengan asal-asalan, hal ini dikarenakan siswa belum mengetahui bagaimana cara menyusun kalimat matematika dari suatu permasalahan dan siswa pun tidak menuliskan serta tidak memahami informasi penting yang ada pada soal. Dengan demikian, kita tarik kesimpulan bahwa siswa tersebut masih sulit untuk menyajikan konsep matematika dalam bentuk representasi lainnya. Hal ini sependapat dengan penelitian Kurniawan yang menyatakan bahwa sebagian besar siswa masih kurang mampu menuliskan apa yang diketahui dan ditanyakan pada soal (Kurniawan et al., 2019).

\section{Indikator: mengaplikasikan konsep algoritma dalam pemecahan masalah.}

Soal nomor 3:

Tentukan penyelesaian dari SPLDV: $2 \mathrm{x}-3 \mathrm{y}=18$ dan $\mathrm{x}+4 \mathrm{y}=-2$ dengan metode substitusi dan eliminasi!

Pada indikator ketiga, yang menjawab dengan benar sebanyak 4 siswa. Berlandaskan pada pedoman penskoran kemampuan pemahaman konsep matematis pada Tabel 1 dan rumus persentase skor kemampuan pemahaman konsep matematis, sehingga cara menghitungnya yaitu dengan mengalikan jumlah siswa yang menjawab benar sebanyak 4 siswa dengan skor jawaban benar yang terdapat pada Tabel 
1 yang bernilai 4 dan hasil dari perkalian tersebut yang didapatkan adalah 16. Kemudian, 16 dibagi dengan skor maksimal yang mungkin dicapai artinya 4 dikalikan dengan subjek penelitian sebanyak 13 siswa yang menghasilkan 52. Oleh karena itu, 16 kita bagi dengan 52 maka diperoleh hasilnya adalah 0,3077 yang kemudian dikalikan dengan 100\%, sehingga diperoleh persentase skor sebesar 30,77\%. Dengan kata lain, bisa diartikan bahwa kemampuan siswa untuk menerapkan konsep algoritma dalam pemecahan masalah dikategorikan kurang. Faktor yang mempengaruhi pemerolehan persentase tersebut dikarenakan kebanyakan guru masih menggunakan metode ceramah yang hanya memfokuskan semua aktivitas belajar mengajar berpusat kepada guru yang menjadikan siswa pasif saat berlangsungnya pembelajaran serta kurangnya siswa dalam berlatih karena belajar matematika itu bias karna terbiasa. Berikut pemaparan kemampuan siswa pada indikator ketiga soal nomor tiga.

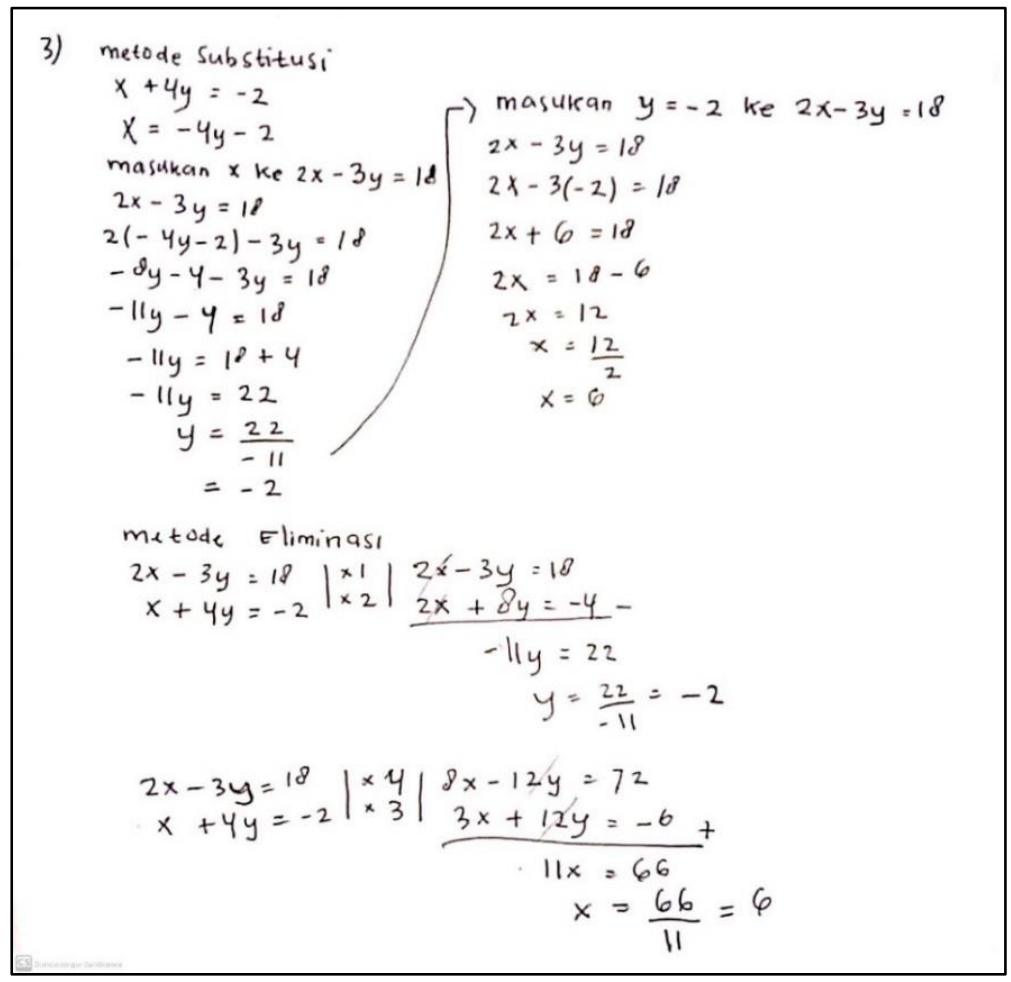

Gambar 5. Jawaban benar siswa

Di soal nomor 3 ini diharapkan siswa mampu mengaplikasikan konsep algoritma dalam pemecahan masalah. Mengacu pada gambar 5 yaitu siswa yang menjawab benar. Nampak bahwa siswa sudah bisa mengaplikasikan rumus metode substitusi dan metode eliminasi sesuai prosedur penyelesaian dalan pemecahan masalah dengan tepat. Terlihat jelas bahwa siswa dapat menemukan nilai $\mathrm{x}$ dan y dengan benar dalam kedua metode tersebut serta pengerjaan yang terurut langkah demi langkah tanpa adanya kekeliruan dalam perhitungan.

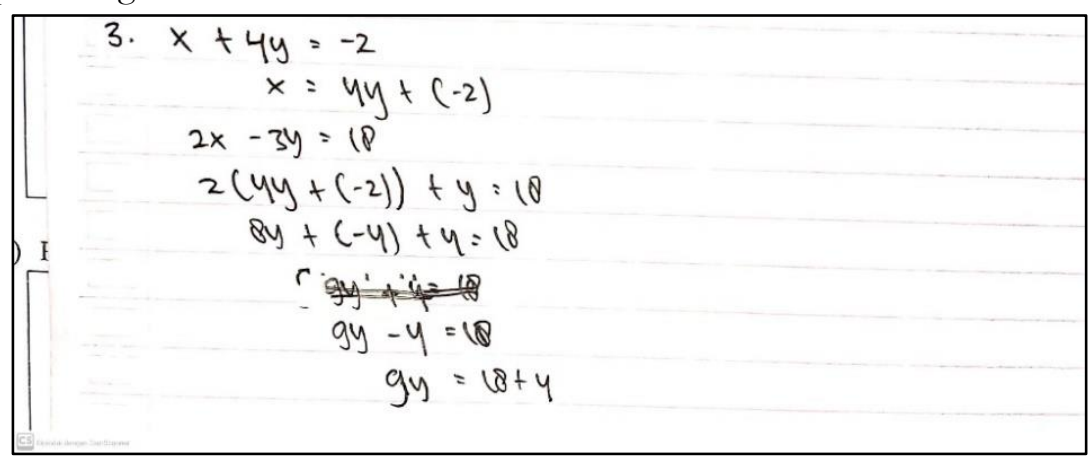

Gambar 6. Jawaban salah siswa

Berdasarkan Gambar 6 yang menunjukkan salah satu siswa yang menjawab salah. Sebenarnya siswa bisa mengoperasikan rumus sesuai prosedur saat mengerjakan soal pemecahan masalah melainkan 
masih terdapat kekeliruan pada perhitungannya dan jawaban siswa tidak lengkap. Terlihat pada saat mensubstitusikan $\mathrm{x}$ ke dalam persamaan yang tiba-tiba nilai $3 \mathrm{y}$ yang terdapat pada soal berubah menjadi $\mathrm{y}$ saja, dengan kekeliruan tersebut menyebabkan kesalahan dalam perhitungan selanjutnya yang mengakibatkan jawaban akhir yang didapat pun menjadi salah. Dengan demikian, siswa tersebut belum dapat mengaplikasikan konsep algoritma dalam pemecahan masalah.

Berdasarkan hasil wawancara siswa dengan jawaban salah, siswa masih sukar dalam penggunaan metode eliminasi dan substitusi. Siswa kesulitan mengelompokkan varibel yang sama dan mana yang harus dicari atau dieliminasi terlebih dahulu, keliru saat mensubstitusikan nilai serta merasa kebingungan dalam setiap langkah-langkah pengerjaannya, itu semua dikarenakan siswa mempunyai pemahaman yang salah tentang metode eliminasi dan substitusi itu sendiri. Sepakat dengan pernyataan (Annisa \& Kartini, 2021) bahwasanya siswa keliru apabila tidak dapat menyusun rumus yang sesuai.

\section{KESIMPULAN}

Berdasarkan hasil analisis jawaban siswa dari tiap butir soal di atas, memperoleh kesimpulan bahwa kemampuan pemahaman konsep matematis siswa kelas IX pada satu MTs di Kabupaten Karawang masih dikategorikan rendah. Hal ini beracuan pada jawaban siswa secara keseluruhan belum memenuhi indikator dari kemampuan pemahaman konsep dengan persentase rata-rata kemampuan pemahaman konsep matematis yang didapatkan sebesar 35,90\%. Dari 3 indikator, hanya 1 indikator yang sudah cukup siswa kuasai yakni pada indikator menyajikan konsep kedalam bentuk representasi matematika, walaupun pada indikator tersebut masih ditemukan siswa yang belum mampu menguasainya. Siswa sulit memahami apa yang diketahui dan dipertanyakan dalam soal, mengubah soal berbentuk prosa menjadi kalimat matematika, dan siswa juga mengalami kendala saat mengimplementasikan konsep penyelesaian secara algoritma dan menentukan cara untuk menyelesaikan persoalan matematika. Adapun faktor yang mempengaruhi rendahnya hasil persentase pemahaman konsep matematika siswa yaitu kurangnya konsentrasi belajar siswa, kebiasaan belajar yang tidak teratur dan metode pembelajaran yang digunakan kurang menarik.

\section{DAFTAR PUSTAKA}

Ananda, R. P., Sanapiah, S., \& Yulianti, S. (2018). Analisis Kesalahan Siswa Kelas Vii Smpn 7 Mataram Dalam Menyelesaikan Soal Garis Dan Sudut Tahun Pelajaran 2018/2019. Media Pendidikan Matematika, 6(2), 79. https://doi.org/10.33394/mpm.v6i2.1838

Andini, U. (2021). Analisis Kemampuan Pemahaman Konsep Siswa dalam Menyelesaikan Soal matematika Materi Pertidaksamaan harga Mutlak. Angewandte Chemie International Edition, 6(11), $951-$ 952., 2(1), 2013-2015.

Annisa, R., \& Kartini, K. (2021). Analisis Kesalahan Siswa Dalam Menyelesaikan Soal Barisan dan Deret Aritmatika Menggunakan Tahapan Kesalahan Newman. Jurnal Cendekia: Jurnal Pendidikan Matematika, 5(1), 522-532. https://doi.org/10.31004/cendekia.v5i1.506

Arifin, Z. (2011). Penelitian Pendidikan Metode dan Paradogma Baru. PT. Remaja Rosdakarya.

Aunurrahman. (2013). Belajar dan Pembelajaran. Alfabeta.

Basir, F., \& Karmila. (2011). Keefektifan strategi konflik kognitif terhadap pemahaman konsep matematika siswa. Prosiding Seminar Nasional ISSN 2443-11909, 02, 83-84.

Fajar, A., Kodirun, \& Arapu, L. (2018). Analisis Kemampuan Pemahaman Konsep Matematis Siswa Kelas VIII SMP Negeri 17 Kendari. 9, 229-239.

Febriyanto, B., Haryanti, Y. D., \& Komalasari, O. (2018). Peningkatan Pemahaman Konsep Matematis Melalui Penggunaan Media Kantong Bergambar Pada Materi Perkalian Bilangan Di Kelas Ii Sekolah 
Dasar. Jurnal Cakrawala Pendas, 4(2), 32. https://doi.org/10.31949/jcp.v4i2.1073

Kartika, Y. (2018). Analisis kemampuan pemahaman konsep matematis peserta didik kelas vii smp pada materi bentuk aljabar. Jurnal Pendidikan Tambusai, 2(2), 777-785.

Kurniawan, A., Juliangkary, E., \& Pratama, M. Y. (2019). Analisis Kesulitan Siswa Dalam Menyelesaikan Soal Fungsi. Media Pendidikan Matematika, 7(1), 72. https://doi.org/10.33394/mpm.v7i1.1679

Lestari, K. E., \& Yudhanegara, M. R. (2018). Penelitian Pendidikan Matematika. PT. Refika Aditam.

Mawaddah, S., \& Maryanti, R. (2016). Kemampuan Pemahaman Konsep Matematis Siswa SMP dalam Pembelajaran Menggunakan Model Penemuan Terbimbing (Discovery Learning). EDU-MAT: Jurnal Pendidikan Matematika, 4(1), 76-85. https://doi.org/10.20527/edumat.v4i1.2292

Purba, A. (2019). Pengaruh Pendekatan Matematika Realistik terhadap Pemahaman Konsep Matematika Siswa. Mosharafa: Jurnal Pendidikan Matematika, 8(2), 191-202. https://doi.org/10.31980/mosharafa.v8i2.454

Putri, P. M. (2012). Pemahaman Konsep Matematika Pada Materi Turunan Melalui Pembelajaran Teknik Probing. Jurnal Pendidikan Matematika Universitas Negeri Padang, 1(1), 68-72.

Yufentya, W. E., Roza, Y., \& Maimunah, M. (2019). Analisis Kemampuan Pemahaman Konsep Siswa Kelas VIII SMP pada Materi Lingkaran. Desimal: Jurnal Matematika, 2(3), 197-202. https://doi.org/10.24042/djm.v2i3.4175

Zuliana, E. (2017). Penerapan Inquiry Based Learning berbantuan Peraga Manipulatif dalam Meningkatkan Pemahaman Konsep Matematika pada Materi Geometri Mahasiswa PGSD Universitas Muria Kudus. Lectura: Jurnal Pendidikan, 8(1). https://doi.org/10.31849/lectura.v8i1.269 